\title{
Competitive Positioning of a Higher Education Institution in Zambia: The Case of ZCAS
}

\author{
Kelvin Mukolo Kayombo, Steve Carter \\ Zambia Centre for Accountancy Studies, Lusaka, Zambia \\ Heriot-Watt University, Edinburgh, Scotland \\ kkayombo@zcas.edu.zm,sc@ebs.hw.ac.uk
}

\begin{abstract}
This study was the second phase of a larger research project that was designed to identify and measure a higher education institution's brand in Zambia in order to ascertain areas for strengthening the brand's competitive position. The objectives of this conjoint study were twofold: firstly, to identify the current position of the ZCAS brand as a case study and secondly, to establish the current position of the ZCAS brand relative to its higher education (HE) competitors in Zambia. This quantitative study involved administering a conjoint questionnaire to 110 first year students in ZCAS and 280 first year students in seven universities in the country. The 19 branding elements identified in the initial qualitative stage of the project were aggregated into five principal branding factors using Atlas.ti's co-occurrence tools to facilitate this conjoint study. These five principal branding attributes are teaching quality, fees, course availability, learning environment and employability. The study revealed that ZCAS has a fairly strong brand position in the Zambian HE sector because the most important elements in its brand model, i.e. course availability, teaching quality and facilities are also the premier brand dimensions in the market. The study also revealed that ZCAS needs to reposition itself away from the competition in order to occupy a more favorable position in the minds of its prospective and existing customers. Accordingly, the study recommends that ZCAS increases its course offerings and collaborates with universities in the region. ZCAS should also consider setting up a quality assurance unit to foster quality in the institution. This study adds to the increasing body of knowledge on HE branding, particularly in developing countries, by developing and then testing a brand orientation model for the Zambian HE market.
\end{abstract}

Keywords: Competitive positioning, brand, higher education, conjoint analysis, Zambia

\section{Introduction}

There is no doubt that the global competition for university students has been on the rise in recent times (UNESCO-UIS, 2016a). According to UNESCO-UIS (2012a), the worldwide increase in competition for students has been spurred by globalization of the higher education marketplace and reduction in state funding to the sector. Bryman and Bell (2011), therefore suggests that to be more competitive, universities must become more brand oriented to increase their visibility, differentiation and market share. The growth in global competition in the HE sector can be seen from the increase in mobility of students globally, regionally and even at national level. For example, between 2000 and 2014 the outbound internationally mobile tertiary students studying abroad more than doubled from 1.8 million to 3.8 million (UNESCO-UIS, 2016b). UNESCOUIS (2012b) shows that in Zambia the number of students studying abroad, even though relatively small, has almost doubled from 2,535 in 1998 to 4,991 in 2010. In the case of Zambia, no published empirical research has yet been carried out on competitive positioning of higher education institutions; hence the country's HEIs may be ill-equipped to compete successfully both regionally and internationally. The design, location and contextual culture of this study are tailored to the Zambian higher education (HE) sector, making it more relevant and justifiable in addressing competitive positioning in the country's HEIs. The research question posed for this study was therefore: 'How can a higher education brand be measured and used for competitive positioning in Zambia?'

\section{Literature Review}

This literature review focuses on competitive positioning in higher education. It covers the sources of competitive advantage, the application of positioning to higher education institutions and the use of perceptual mapping in positioning. A discussion of sources of competitive advantage that can be used in positioning HEIs in Zambia is also provided. 
Sources of competitive advantage: A brand's competitive advantage arises from two sources, namely cost leadership and differentiation (De Chernatony, McDonald \& Wallace, 2011, pp.324-329; Dibb, Simkin, Pride, \& Ferrell, 2006, pp.49-50; Porter, 1985, p.3). These two sources are not mutually exclusive and can be applied to entire markets or focused on market niches. De Chernatony et al. (2011, pp.324-329) posit that cost leadership creates value for consumers because it costs them less to buy the brand than competing brands offering similar benefits ('cost-driven' brands e.g. EasyJet, McDonald's, Aldi, Lidl and Travelodge), while differentiation creates unique benefits for consumers ('value-driven' brands e.g. Apple Mac, Porsche and Harrods' Food Hall). Kotler and Keller (2012, p. 312) suggest that differentiating a brand from competing brands can be achieved in several ways. These include employee differentiation, channel differentiation, image differentiation and service differentiation. On the other hand, cost leadership can be achieved through selecting cheaper sources of raw materials, volume discounts, economies of scale, use of technology in production, dealing with large order customers only, rationalizing the product/service range, gaining experience faster than competitors and reducing service levels (De Chernatony et al., 2011, pp.323-324).

In order to compete effectively, a firm should understand its micro and macro competitive environments (Kotler \& Keller, 2012, pp.298-301; De Chernatony et al., 2011, pp.324-329; Dibb et al., 2006, pp.50-52). Porter's Five Forces model (with competitors, suppliers, buyers, substitute products and new entrants as the forces) or similar adaptations such as Interbrand Five Forces (competitors, distributors, consumers, corporation and macro-environment) that influence brand potential can be used to analyze the competitive environment (De Chernatony et al., 2011, pp.58-63; Dibb et al., 2006, pp.51-52; Porter, 1985, pp.4-5). Originally designed for commercial organizations, these models can be applied to higher education because of the competitive environment in which HEIs are now operating and their increased commercialization and marketisation. Porter's model for example, has been used in studies in higher education such as Huang's (2012) and Mazzarol and Soutar's (1999) research on competitive advantage in Taiwanese and international HE respectively.

Sources of competitive advantage in Zambian HEIs: Kayombo and Carter (2016) identified course availability, teaching quality, facilities and infrastructure as the top four sources of competitive advantage in the Zambia HE marketplace (see Figure 1 below). Credibility, fees, and employability were tied in fifth place. These findings were similar to other research findings such as Huang (2012), and Lynch and Baines (2004), although the degree of importance of the factors was different due the differing economic environments in which the studies were carried out. These factors form the basis for the competitive positioning study between ZCAS and its competitors in Zambia.

Figure 1: Sources of competitive advantage in the HE sector in Zambia (Kayombo \& Carter, 2016)

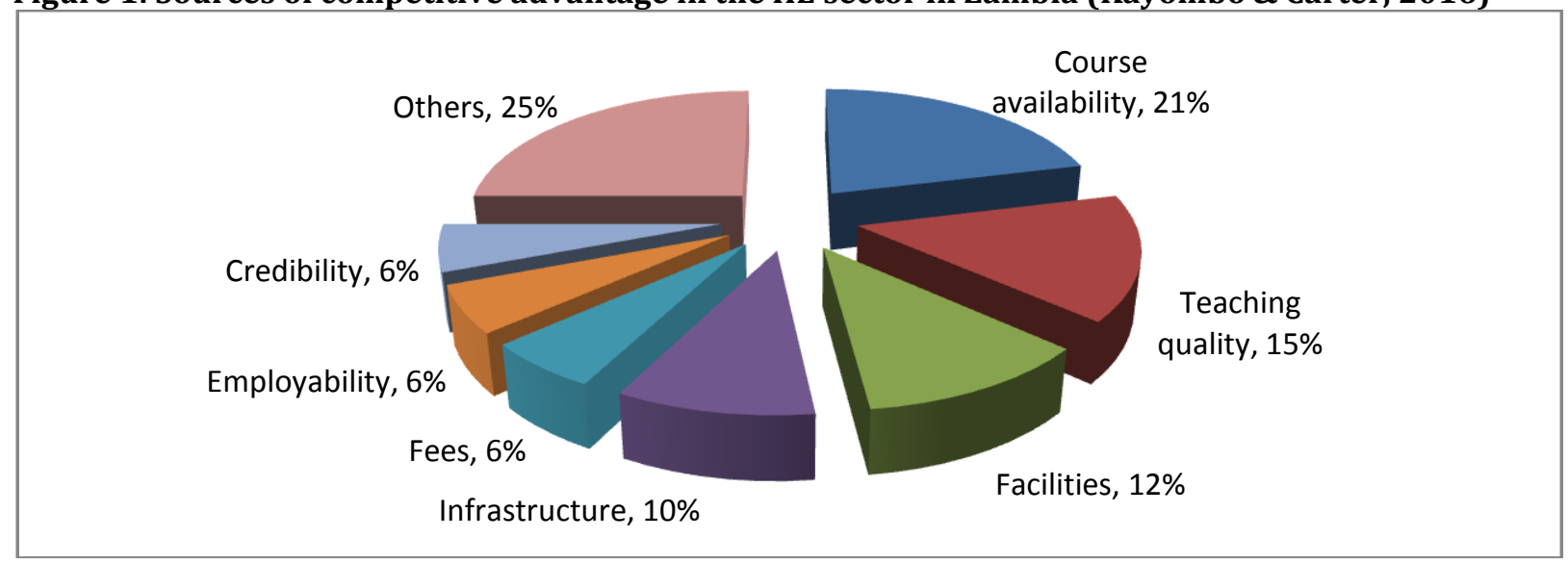

Competitive positioning: Dibb et al. (2006) and Ries and Trout (2001) view positioning as the act of designing a company's offering and image to occupy a distinctive place in the mind of the prospect (target market). Positioning can be done to anything or anyone e.g. a product, organization or CEO (Kotler \& Keller, 2012; Ries \& Trout, 2001). It follows therefore that in the context of universities and colleges, it should be possible to brand or position the institution as a whole (e.g. Harvard or Cambridge or Oxford), a school within 
the university (e.g. Stanford Graduate School of Business, Harvard Business School or London Business School) or the programs offered (e.g. Global MBA). Furthermore, positioning could be done to key employees such as the vice chancellor or CEO or even to a specific campus location.

Kotler and Keller (2012) assert that 'positioning requires that marketers define and communicate similarities and differences between their brand and its competitors'. They recommend three stages, namely:

- Determine target market and competitive environment;

- Identify optimal points of difference (PODs) (unique and superior brand attributes or benefits perceived desirable, deliverable and differentiating by consumers) and points of parity (POPs) (essential brand attributes or benefits shared by other brands). Choice of specific PODs and POPs can be done using perceptual maps - visual depictions of consumer perceptions and preferences to identify 'holes' or 'openings' of unmet consumer needs and marketing opportunities.

- Create a brand mantra ('brand essence', 'core brand promise' or articulation of the heart and soul of the brand) to summaries the positioning and essence of the brand.

Kotler and Armstrong (2005) assert that product/service and corporate brands can be positioned based on three levels. They illustrate these levels using toothpaste. At the lowest level, positioning can be based on attributes (e.g. toothpaste's innovative ingredients and good taste). Secondly, positioning could be based on desirable benefits (e.g. the toothpaste's cavity prevention and teeth whitening benefits). Finally, product/service and corporate brands can be positioned based on beliefs and values (e.g. emotions such as 'healthy, beautiful smiles for life'). Various competitive positions can also be adopted in different market segments, for example, as market leader, market challenger, fast mover, market follower or market nicher (Dibb et al., 2006).

University brand positioning: Most university brand positioning studies have required research participants to rank/rate individual brand factors that attract/attracted them to the HEI (Afful-Broni \& Noi-Okwei, 2010; Ali-Choudhury et al., 2009; Carter \& Yeo, 2009; Krampf \& Heinlein, 1981; Songan et al., 2010). Although these studies succeeded in identifying the important branding factors that attracted the students to the universities, simply rating/ranking the university choice criteria does not reflect the actual decision process of consumers who are faced with multiple attributes. As Hooley and Lynch (1981) observe, consumers faced with multiple attributes consider personal constraints and trade off preferable factors for less attractive ones in making university choices. In order to overcome this deficiency, other studies have used conjoint analysis principles by asking participants to rank bundles of factors in a tradeoff situation (Hagel \& Shaw, 2008; Hooley \& Lynch, 1981; Kusumawati, 2011; Moogan, Baron, \& Bainbridge, 2001; Soutar \& Turner, 2002). Conjoint analysis reveals the relative importance of each attribute in the decision process and therefore mimics the actual thought processes of consumers. However, the technique fails to identify the consumer's perception of the importance of individual attributes.

The current study combined both approaches. The first section of the data collection instrument elicited research participants to rank the university choice criteria, while the conjoint experiment was carried out in the second section of the questionnaire. By combining both approaches, the current study does not only reveal the branding factors that students perceive to be important, but also those elements' relative significance in the actual decision process. In the context of this study, the research objectives are therefore as follows:

- to identify the current position of the ZCAS brand as a case study; and

- to establish the current position of the ZCAS brand relative to its higher education competitors in Zambia.

Perceptual mapping: To achieve the research objectives above, perceptual maps based on students' perception of their respective HEIs were constructed. Kotler and Keller (2012, p.305) define perceptual maps as 'visual representations of consumer perceptions and preferences'. By depicting consumers' views on products/services using various attributes, marketers can identify consumer needs that are yet to be met and marketing opportunities yet to be exploited. Kotler and Armstrong (2005) refer to perceptual maps as positioning maps or perceptual positioning maps. These maps can be used in planning positioning strategies because they depict consumers' views of an organization's brands versus competing brands on principal 
buying dimensions. The company's offerings can therefore be more appropriately positioned or repositioned. According to Fill (2006, pp.378-379) brand maps can serve several roles including:

- Determining the level of competition in a market (the closer the brands are clustered together, the greater the competition).

- Identifying substitute products - substitute products are normally close to each other on the map.

- Identifying ideal brands i.e. the most preferred combination of brand attributes in a market. The ideal brand's position can be used to position or reposition an organization's brands.

- Developing and evaluating the effectiveness of marketing strategies in affecting consumer perceptions.

\section{Methodology}

This section outlines the methodology that was adopted to implement the study. The study was quantitative in approach. The survey strategy, utilizing a conjoint questionnaire, was chosen for the research. The conjoint analysis technique in SPSS was used in data analysis. These methodological choices are discussed in detail below.

Conjoint survey: A survey utilizing a conjoint questionnaire based on the HE branding components identified by Kayombo and Carter (2016) was used to measure the extent of brand positioning among a sample of HEIs in Zambia. Hooley and Lynch (1981) define conjoint analysis as 'a de-compositional approach to modeling the relative importance of individual attribute components in creating overall preference for multi-attribute alternatives'. Conjoint analysis seems to mimic the actual decision making process because of the assumptions inherent in the technique such as people evaluating a limited number of options as bundles of attributes rather than as whole products; and compensating good performance on one attribute for poor performance on others (Kusumawati, 2011). In order to ensure credibility of the conjoint study, the experiment was based on the seven stage process in Hair, Black, Babin, and Anderson (2010). The research procedure for this study is illustrated in Figure 2 below.

\section{Figure 2: Research procedure}

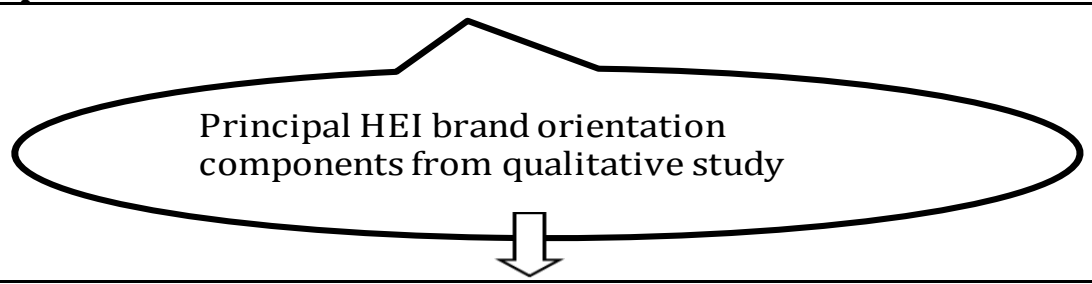

Develop interview questionnaire using SPSS Conjoint Orthoplan
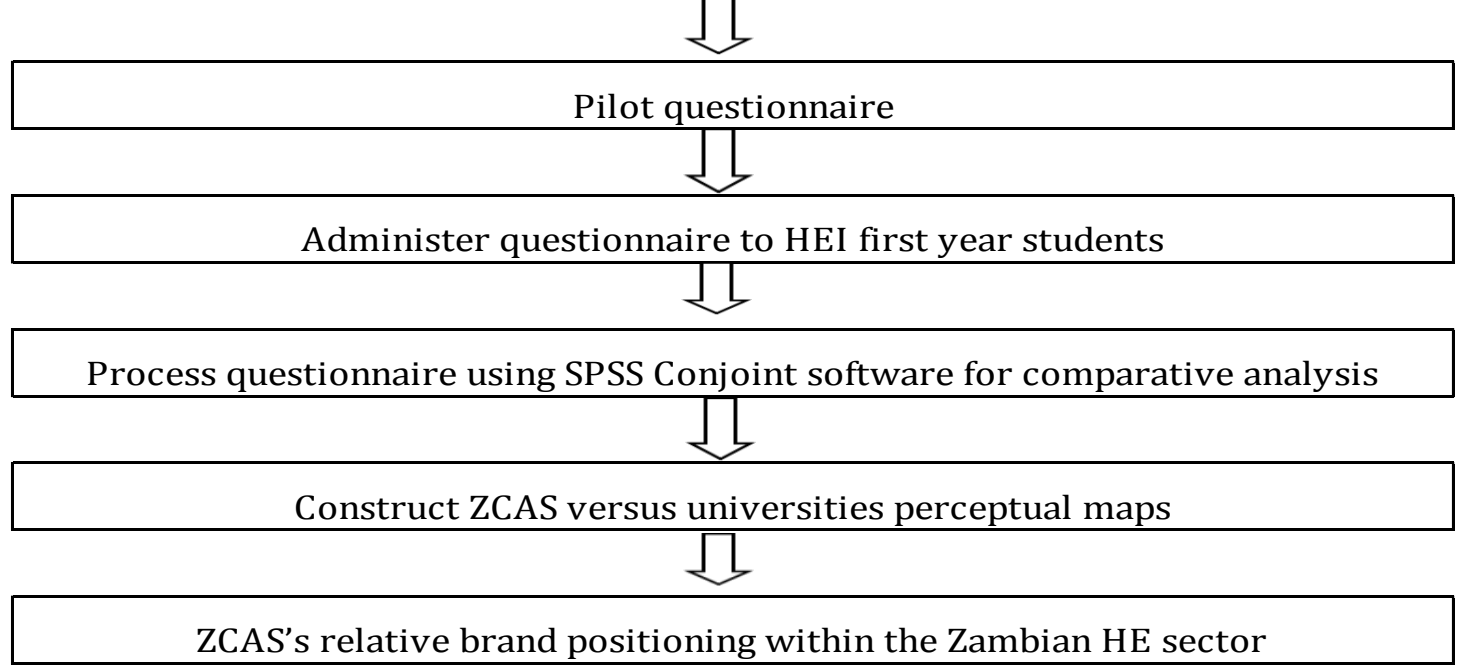
Attributes and attribute levels for conjoint study: The qualitative study reported by Kayombo and Carter (2016), which was the first phase of the current research, identified 19 branding factors that students consider when choosing Zambian HEIs. Such a large number of attributes would be impossible to manage in a conjoint experiment. Therefore, Atlas.ti's co-occurrence tools were used to derive five factors from the 19 to facilitate the conjoint study. These were academic reputation, fees, course availability, employability and learning environment. These factors and their respective levels are described in Table 1 below.

\section{Table 1: Attributes and attribute levels}

\begin{tabular}{|c|c|c|c|c|}
\hline No & Attribute & Description & Attribute level & Adapted from \\
\hline 1 & $\begin{array}{l}\text { Academic } \\
\text { reputation or } \\
\text { teaching } \\
\text { quality }\end{array}$ & $\begin{array}{l}\text { This refers to the fame of the HEI and } \\
\text { the esteem in which it is held by the } \\
\text { public. Many factors affect academic } \\
\text { reputation, including, age of institution; } \\
\text { attitude, qualifications and experience } \\
\text { of staff. }\end{array}$ & $\begin{array}{ll}\text { a) } & \text { Outstanding } \\
\text { b) } & \text { Average } \\
\text { c) } & \text { Poor }\end{array}$ & $\begin{array}{l}\text { Hooley \& Lynch, } \\
\text { 1981; } \\
\text { Kusumawati, } \\
\text { 2011; Moogan et } \\
\text { al., 2001; Soutar \& } \\
\text { Turner, 2002 }\end{array}$ \\
\hline 2 & $\begin{array}{l}\text { Total } \\
\text { expenses }\end{array}$ & $\begin{array}{l}\text { Total fees payable for entire program as } \\
\text { well as flexibility in payment methods. } \\
\text { Also included are discounts, availability } \\
\text { of scholarships and bursaries. }\end{array}$ & 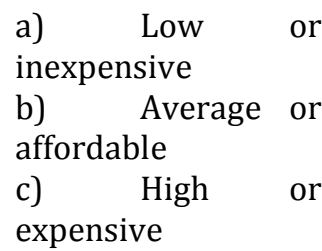 & $\begin{array}{l}\text { Hagel \& Shaw, } \\
\text { 2008; } \\
\text { Kusumawati, } 2011\end{array}$ \\
\hline 3 & $\begin{array}{l}\text { Course } \\
\text { availability }\end{array}$ & $\begin{array}{l}\text { This refers to the number of programs } \\
\text { and courses a HEI offers. It also refers to } \\
\text { whether the courses are available on full } \\
\text { time, part time, distance learning, e- } \\
\text { learning and block release. }\end{array}$ & $\begin{array}{l}\text { a) Just what I } \\
\text { want } \\
\text { b) More or } \\
\text { less what I want } \\
\text { c) Not really } \\
\text { what I want }\end{array}$ & $\begin{array}{l}\text { Hooley \& Lynch, } \\
\text { 1981; Moogan et } \\
\text { al., 2001; Soutar \& } \\
\text { Turner, } 2002\end{array}$ \\
\hline 4 & $\begin{array}{l}\text { Employability } \\
\text { (job } \\
\text { prospects) }\end{array}$ & $\begin{array}{l}\text { This refers to the availability of } \\
\text { employment opportunities upon } \\
\text { graduating from the HEI. }\end{array}$ & $\begin{array}{l}\text { Good } \\
\text { Average } \\
\text { Poor }\end{array}$ & $\begin{array}{l}\text { Kusumawati, } \\
\text { 2011; Soutar \& } \\
\text { Turner, } 2002\end{array}$ \\
\hline 5 & $\begin{array}{l}\text { Learning } \\
\text { environment }\end{array}$ & $\begin{array}{l}\text { This is the aura, climate and general feel } \\
\text { of the university including its location, } \\
\text { infrastructure and facilities (e.g. } \\
\text { libraries, learning materials and IT } \\
\text { facilities); also includes physical aspects } \\
\text { of environment such as cleanliness, } \\
\text { hygiene, greens and architecture. }\end{array}$ & $\begin{array}{l}\text { Conducive } \\
\text { Average } \\
\text { Poor }\end{array}$ & $\begin{array}{l}\text { Kusumawati, } \\
\text { 2011; Soutar \& } \\
\text { Turner, } 2002\end{array}$ \\
\hline
\end{tabular}

Sampling frame and sample size: The sampling frame for this study comprised a list of first year students in all the $20 \mathrm{HE}$ institutions that were considered for the study. Such a list was impracticable to obtain as some of the universities were reluctant to provide detailed information about their students. Consequently, probability sampling was not used due to the absence of a sampling frame (Saunders, Thornhill, \& Lewis, 2009). Instead, non-probability sampling, and in particular, quota sampling techniques were employed in selection of the sample, with quotas being determined by the geographical location of the universities. Even though quota sampling is non-random, it is assumed that the sample represents characteristics of the population because of the quotas selected (Bryman \& Bell, 2011; Saunders et al., 2009).

Samples selected other than by probability sampling (except quota sampling as argued by some researchers) are generally considered to be unrepresentative of the population, hence results might not be generalizable to the population. However, Bryman and Bell (2011, pp.187-188) and Saunders et al. (2009, pp.217-218) assert that the error of generalizing to the population reduces as the absolute sample size increases because the distribution of a large sample is closer to the normal distribution. It is therefore envisaged that the large sample of 390 respondents in this phase of the study, albeit selected non-randomly, facilitates statistical inferences to be made about the population. In the case of ZCAS where there are several tuition delivery methods (e.g. full time and evening/part time classes), sample representativeness was enhanced because the 
quota system ensured that most aspects of the population were considered; for example, part time students, full time students, students undertaking degree programs and those on professional courses were included in the sample (Bryman \& Bell, 2011, p.193; Saunders et al., 2009, p.235). It is envisaged that this procedure also assisted in minimizing systematic error that could result from quota sampling.

Conjoint questionnaire design and administration: The conjoint procedure in IBM SPSS Statistics 20 was used to generate an orthogonal array of 22 attribute combinations (i.e. 18 experimental attribute bundles and four holdout cases). Hair et al. (2010) strongly recommend that in order to ascertain the validity or prediction power of the conjoint model, holdout cases should be included in the conjoint profile list. Holdout cases are factor-level combinations similar to the orthogonal array generated for the study. They are rated by survey participants but are not used in building the preference model. In line with similar conjoint studies such as Hagel and Shaw (2008), Hooley and Lynch (1981), and Kusumawati (2011), four holdout cases were included among the 22 stimulus cards. The questionnaire designed for the study (see Appendix 1) was pre-coded and pilot tested to enhance its reliability, validity and practicability (Bryman \& Bell, 2011; Saunders et al., 2009). 20 pilot 'cards' or questionnaires were printed to elicit a sample of first year students' views on the practicability of this data collection instrument. Following the pilot study, adjustments were made, including a change in design and administration of the questionnaire. An example of the resultant full profile card is shown in Table 2 below.

Table 2: An example of a Full Profile Card and rating criteria

\begin{tabular}{|c|c|c|c|c|c|c|c|c|c|c|}
\hline \multicolumn{6}{|c|}{ Bundle Number 3} & \multirow[b]{2}{*}{$\begin{array}{l}\text { Strongly } \\
\text { disagree }\end{array}$} & \multirow[b]{2}{*}{ Disagree } & \multirow[b]{2}{*}{$\begin{array}{c}\text { Neither } \\
\text { agree nor } \\
\text { disagree }\end{array}$} & \multirow[b]{2}{*}{ Agree } & \multirow[b]{2}{*}{$\begin{array}{c}\text { Strongly } \\
\text { agree }\end{array}$} \\
\hline $\begin{array}{c}\text { Card } \\
\text { ID }\end{array}$ & $\begin{array}{c}\text { Academic } \\
\text { reputation or } \\
\text { teaching quality of } \\
\text { institution }\end{array}$ & $\begin{array}{l}\text { Total expenses } \\
\text { for entire } \\
\text { program until } \\
\text { completion } \\
\end{array}$ & $\begin{array}{c}\text { Job } \\
\text { prospects }\end{array}$ & \begin{tabular}{|c|} 
Learning \\
environment \\
and facilities
\end{tabular} & $\begin{array}{c}\text { Availability of } \\
\text { course }\end{array}$ & & & & & \\
\hline 3 & Poor & High & Good & Average & $\begin{array}{c}\text { Just what I } \\
\text { wanted }\end{array}$ & & & & & \\
\hline
\end{tabular}

A questionnaire survey was conducted in ZCAS, the main case study organization, and seven universities. Of these eight HEIs, two represented six public HEIs (about 33\%) while the rest represented 14 of the private universities in the country (about 43\%). In terms of geographical spread two were from seven of the HEIs in the north of the country (about 29\%), five were from 11 of those in Lusaka or central Zambia (about 45\%) and one was from the two in the south (50\%). The sample size of 390 students from eight out of 20 HEIs was considered large enough to enable statistical inferences to be made about the population. Many similar studies have been conducted in a much smaller number of universities (Afful-Broni \& Noi-Okwei, 2010; Hagel \& Shaw, 2008; Wiese et al., 2009). First year students were considered suitable because they had just gone through the HE decision making process and were therefore more likely to have fresher memories of the branding dimensions considered than final year students, for example. Many similar studies have focused on first year undergraduate students to elicit HE branding dimensions (Afful-Broni \& Noi-Okwei, 2010; Carter \& Yeo, 2009; Kusumawati, 2010).

390 questionnaires were administered to students during classes, thereby assuring a high response rate. Given that the response rate was $100 \%$, this sample was quite large for a conjoint study and helped in controlling measurement error. The use of a conjoint questionnaire survey in this research project was reinforced by other branding studies in a university context (Hooley \& Lynch, 1981; Kusumawati, 2011; Soutar \& Turner, 2002). All questionnaires were cross-checked for errors and incomplete sections. Erroneously completed and incomplete questionnaires were discarded before further processing. IBM SPSS 20 was used to process and analyze the questionnaire data, with student perceptions of their HEI brand attributes being the unit of measurement.

Credibility of research findings: Saunders et al. (2009) assert that reliability in survey research employing a questionnaire largely depends on questionnaire design, structure and rigor of pilot testing. In the context of this study, the conjoint questionnaire was generated using SPSS Conjoint Orthoplan and Plancards software and was pilot-tested within ZCAS, thereby enhancing its reliability, validity and practicability. Reliability of 
the actual questionnaire results was measured using Cronbach's alpha, $\alpha$, which is a very common measure of internal reliability (Bryman \& Bell, 2011). Having processed the conjoint questionnaire results in SPSS, the reliability statistics generated indicated Cronbach's alpha of .779 and Cronbach's alpha based on standardized items of .795. Both values were above 0.7, indicating that the questionnaire measured what it intended to measure; hence the results could be taken as reliable. Validity of the findings was established in two ways. Firstly, by using triangulation (Bryman \& Bell, 2011; Saunders et al., 2009), the findings from this study (i.e. students' perceptions of their HEI brands) were compared to the research findings from the first research reported by Kayombo and Carter (2016). Secondly, goodness-of-fit measures (i.e. Pearson's R and Kendall's tau) were calculated for the estimation and hold-out samples in the conjoint experiment (Hair et al., 2010; IBM, 2011).

\section{Findings and Discussion}

This section is an outline and analysis of the research findings. As stated above, the objectives of this conjoint study were twofold: firstly, to identify the current position of the ZCAS brand as a case study; and secondly, to establish the current position of the ZCAS brand relative to its higher education competitors in Zambia. The research findings and analysis are presented on the basis of these objectives.

ZCAS' brand position in the Zambian higher education sector: In order to identify the current position of the ZCAS brand, a conjoint questionnaire was administered to a sample of 110 first year students in ZCAS. The questionnaire required the research participants to rate factor profiles based on the principal branding elements that attracted them to the institution. Their ratings for choosing ZCAS were then compared to the principal branding elements in Zambia as ascertained in the first research reported by Kayombo and Carter (2016). Of the 110 questionnaires administered at ZCAS, 6 were found unusable due to missing data, leaving a total of 104 that were used in the analysis. $70 \%$ of the respondents were female while the rest were male. In terms of age $58 \%$ were aged 25 or lower, $24 \%$ were aged between 26 and 35 years while $18 \%$ were over 35 years old. The demographic data were as expected. For example, more females are entering higher education in Zambia due to calls by the government and civil society organizations to educate the girl-child. Similar recent studies have also found more female than male respondents in African HEIs (Afful-Broni \& Noi-Okwei, 2010; Wiese et al., 2009).

Ranking of the five main branding elements by ZCAS students: The first part of the questionnaire required respondents to rank the five main branding factors from number 1 to 5 , with the most important factor that attracted the student to ZCAS being ranked number 1 and the least important as number 5 . As shown in Figure 3 below, half of the sampled ZCAS students ranked course availability as their greatest attraction to ZCAS. Academic reputation was ranked second (by 33\%), followed by learning environment (by 9\%) and employability (by 7\%) in third and fourth places respectively. ZCAS fees were not considered attractive. In the case of ZCAS, the ranking of course availability as the number 1 attraction could be because the institution offers tuition for world renowned professional qualifications such as ACCA, CIMA, CIM and CIPS). Additionally, the institution offers undergraduate and post graduate degree programs in collaboration with highly rated world class partners such as the London School of Economics and Political Science. ZCAS therefore seems to benefit from these strong brands as the courses offered are highly reputed and very attractive to potential students. With regard to teaching quality, ZCAS maintains stringent quality controls over lecturers. For example, whereas punctuality and absenteeism from class may be a common challenge for lecturers in public universities in Zambia, ZCAS lecturers are strictly monitored to ensure that learning is not disrupted. Coupled with a student-centered organizational culture, ZCAS seems to have created a favorable perception of the institution's academic reputation. 
Figure 3: Individual ranking of branding elements by ZCAS and University students

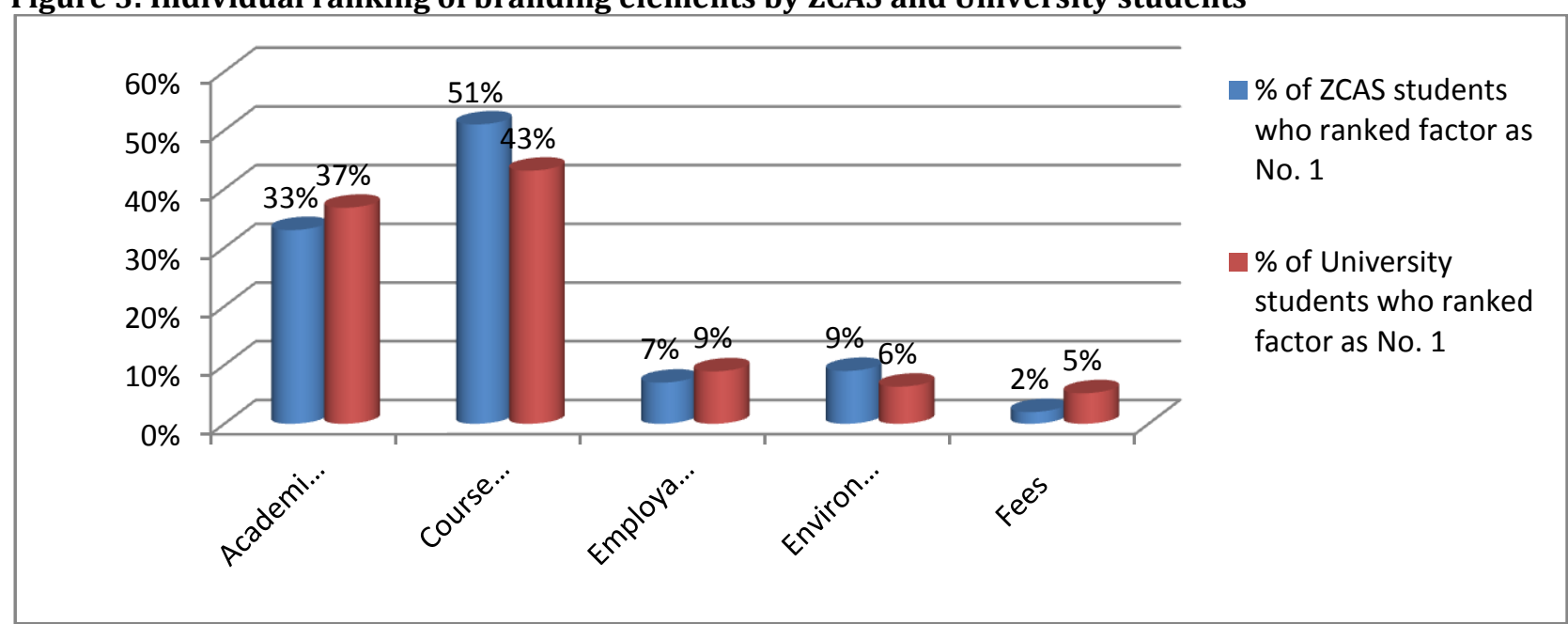

Similarly, it is not surprising that the learning environment at ZCAS came third in the ranking. ZCAS boasts of relatively good facilities; and from the researcher's visits to most HEIs, very few can compare with ZCAS' infrastructure and facilities in the country. Fees charged by ZCAS were ranked as the least attractive factor. This is understandable too, given that, unlike most other students in government HEIs, ZCAS students do not have access to government bursaries and therefore have to pay the full commercial fees the institution charges. The findings from the direct ranking of the factors by ZCAS students are similar to those for other studies in an African context. For example, Afful-Broni \& Noi-Okwei (2010) found that academic reputation, availability of desired program and quality of teaching had the most influence on students' choice of a Ghanaian university, while Wiese et al. (2009) concluded that teaching quality exerted the most influence on HE choice in a sample of South African universities. Similarly, these studies found that fees were not of much concern to students.

ZCAS conjoint analysis: The conjoint module in IBM SPSS 20 software was used to analyze the data. Reliability of the questionnaire results was measured using Cronbach's $\alpha$, which at 0.779 indicated that the results could be taken as reliable. A description of the conjoint model is given in Table 3 below. The model assumes that potential students consider branding elements as a bundle or set, not as individual factors. A deficiency in one factor can therefore be traded off or off-set by other factors when choosing a particular HEI. The model also assumes that the relationship between the factors and scores is linear i.e. for reputation, employability, environment and course availability, the higher the respondent's score, the greater the preference or utility for that factor. On the other hand, the presumed preference structure for fees has an inverse linear relationship between scores and preference, i.e. the higher the level of fees, the lower the preference.

Table 3: Conjoint Model Description

\begin{tabular}{lll}
\hline Factor & Number of Levels & Relation to Scores \\
\hline Reputation & 3 & Linear (more) \\
Fees & 3 & Linear (less) \\
Employability & 3 & Linear (more) \\
Environment & 3 & Linear (more) \\
Course & 3 & Linear (more) \\
\hline
\end{tabular}

All factors are orthogonal. 
Three goodness-of-fit measures were provided by the analysis software i.e. Pearson's correlation and Kendall's tau for the estimation sample as well as Kendall's tau for the validation sample. These measures are as shown in Table 4 below. Hair et al. (2010) assert that for an estimation process involving 18 profiles and five attributes (as was the case in this conjoint study), the minimum correlation should be .55 , while a correlation of .707 would be required if the estimation process was to explain at least $50 \%$ of the variation. The high correlation statistics for the estimation sample (i.e. Pearson's $r$ of .936 and Kendall's tau $\tau$ of .708) indicates strong fit between the model and the obtained data and strongly suggests that the conjoint analysis was valid. Similarly, the Kendall's tau for hold-outs of 1.000 indicates strong correlation between the predicted model and the validation sample. Given that the hold-out set had only four profiles, a high Kendall's tau suggests overall suitability of the main effects model (Hair et al., 2010; Kusumawati, 2011).

Table 4: Goodness-of-fit measures for ZCAS and Universities Conjoint, Correlations ${ }^{a}$

\begin{tabular}{lllll}
\hline & Value & & Sig. & \\
\hline & ZCAS & Universities & ZCAS & Universities \\
Pearson's R & .936 & .883 & .000 & .000 \\
Kendall's tau & .708 & .638 & .000 & .000 \\
Kendall's tau for Holdouts & 1.000 & .667 & .021 & .087 \\
\hline
\end{tabular}

a. Correlations between observed and estimated preferences

The conjoint analysis results revealed that ZCAS' academic reputation/teaching quality (30\%) was the most important attribute in attracting students to the institution. This was followed by course availability (20\%), learning environment (18\%), fees (16\%) and lastly employability (15\%). The results are as shown in Figure 4 below.

Figure 4: ZCAS and Universities averaged importance values

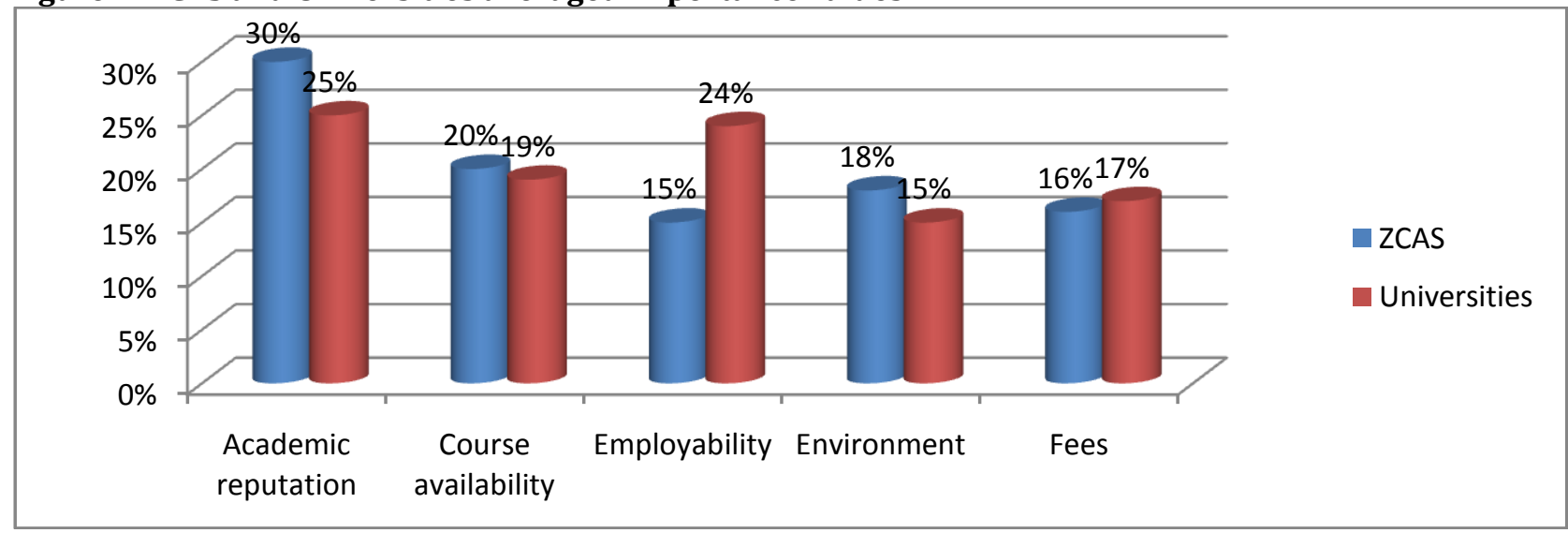

As shown in Table 5 below, further analysis of the conjoint results suggests that ZCAS students had high preference for outstanding teaching quality (with mean utility of 1.370). The preference level declined as the teaching quality deteriorated. Similar attribute level results were also observed for employment prospects, learning environment and course availability. Surprisingly, the results suggest that ZCAS students prefer high fees (mean utility $=.459$ ) to average fees (mean utility .306) and worse still low fees (mean utility $=.153$ ). This could be because:

- As suggested by some of the interviewees during the qualitative phase of the study, low fees signal poor quality of service; hence students and their sponsors found comfort in higher fees.

- Since most of the first year students are sponsored by their parents, guardians or employers (who did not take part in the survey), fees may not pre-occupy them so much because they may not directly experience the impact of high fees. 
- Research participants were already enrolled in the institution, implying that they could afford the fees. The impact of fees on the HE choice decision might have been different if the survey had been conducted among prospective students.

The ZCAS conjoint analysis results are similar to those from other studies. For example, Hooley and Lynch (1981), and Soutar and Turner (2002) identified course suitability and academic reputation as top three preference factors. However, the results are not entirely congruent with those for the direct ranking of the branding factors shown in Figure 3 above. For example, whereas ZCAS students ranked course availability $(51 \%)$ and teaching quality (33\%) as their respective number 1 and number 2 major attractions to the institution, the conjoint experiment suggests that teaching quality (30\%) plays a more important role than course availability (20\%) when it comes to making actual choices in a tradeoff situation. Therefore, the model assumption that potential students consider personal constraints and perceive HE choice criteria as bundles of factors when choosing higher education institutions is upheld. In other words, even though potential ZCAS students think that course availability is their major attraction to ZCAS, this factor is traded-off against the other factors, particularly teaching quality, in the final choice of HEI. Similarly, even though employability was ranked above fees in the direct ranking, fees play a slightly more important role in the final HEI choice decision.

Table 5: ZCAS and Universities conjoint attribute level utilities

\begin{tabular}{llllll}
\hline Attribute & Attribute level & \multicolumn{2}{l}{ Utility Estimate } & \multicolumn{2}{l}{ Std. Error } \\
\hline \multirow{3}{*}{ Reputation } & ZCAS & Universities & ZCAS & Universities \\
& Poor & .457 & .395 & .068 & .090 \\
& Average & .913 & .790 & .136 & .180 \\
Outstanding & 1.370 & 1.185 & .203 & .270 \\
Fees & Low & .153 & .041 & .068 & .090 \\
& Average & .306 & .082 & .136 & .180 \\
Employability & High & .459 & .124 & .203 & .270 \\
& Poor & .140 & .374 & .068 & .090 \\
Environment & Average & .280 & .747 & .136 & .180 \\
& Good & .421 & 1.121 & .203 & .270 \\
& Poor & .264 & .078 & .068 & .090 \\
& Average & .527 & .156 & .136 & .180 \\
Conducive & .791 & .234 & .203 & .270 \\
Course & Not really what & .258 & .199 & .068 & .090 \\
& I wanted & & & & .180 \\
More or less & .516 & .397 & .136 & .270 \\
\hline & what I wanted & & & .203 & .270 \\
\hline & Just what I & .774 & .596 & .396 & .409 \\
\hline
\end{tabular}

The research objective applicable to this phase of the study is: To identify the current position of the ZCAS brand as a case study. In order to establish this research objective, students' perceptions about the ZCAS brand from both the direct ranking and conjoint analysis in the current research were compared to the Zambian principal branding factors identified in the earlier qualitative stage of the project. The results from the direct ranking and conjoint analysis discussed above indicate that teaching quality and course availability play a crucial role in students' perception and choice of ZCAS. These two brand factors are also very important branding elements in the Zambian HE market because the content analysis carried out in the qualitative stages of the research project identified teaching quality as the most important branding factor in 
Zambia, while course availability was seen as the most significant source of competitive advantage by Zambian university marketing executives (Kayombo \& Carter, 2016). It can therefore be concluded that ZCAS has a strong brand position in the Zambian HE market because its premier brand factors i.e. teaching quality and course availability are also the most important in the country as a whole.

ZCAS' comparative brand position in the Zambian higher education sector: In order to investigate the second research objective regarding the current position of the ZCAS brand relative to its HE competitors in Zambia, the conjoint questionnaire was also administered to 280 first year students in seven universities. 269 questionnaires were found usable for the analysis. $94 \%$ of the respondents were aged 25 and below while $54 \%$ were female. Unlike the ZCAS sample that comprised full time and evening students, all university respondents were full time students as most such institutions do not offer evening classes. This explains why most of the respondents were aged 25 and below.

Ranking of the five main branding elements by university students: As shown in Figure 3 above, course availability (43\%) and academic reputation (37\%) were ranked as the two most important factors in student choice of university. Like other studies in an African context such as Afful-Broni and Noi-Okwei (2010) and Wiese et al. (2009), the other factors played a limited role (employability 9\%; environment 6\% and fees 5\%). Except for environment and employability (ranked third and fourth respectively by ZCAS students), the positions of the other factors are identical to ZCAS. Employability seems to be of greater concern to university students than ZCAS students. This could be because students in private universities were concerned about the recognition of these institutions. Qualifications obtained from private universities might therefore be perceived to be less attractive on the job market, hence this factor having a greater bearing on the choice decision.

Universities conjoint analysis: The conjoint analysis results presented in Figure 4 above revealed that academic reputation $(25 \%)$ had the most influence on choice of university. This was closely followed by job prospects (24\%). Course availability (19\%), fees (17\%) and learning environment (15\%) had less impact on university choice decision. Further analysis of the conjoint results suggests that university students had high preference for outstanding teaching quality with mean utility of 1.185 (see Table 5 above). The preference level declined as the teaching quality deteriorated. Similar attribute level results were also observed for employment prospects, learning environment and course availability. Surprisingly, university students, just like their ZCAS counterparts, do not mind higher fees. Similar reasons as to why fees are not a significant influence on ZCAS students' choice decision may also be at play here i.e. low fees signaling poor quality and fees not being an issue because the students themselves not actually being the ones paying the fees, for example. Additionally, for students in public universities, Government bursaries help to cushion the impact of high fees, resulting in this factor having a reduced bearing on university choice decision.

The conjoint analysis results for university students are not entirely congruent with those for the direct ranking of the branding factors shown in Figure 3 above. As for ZCAS students, it is interesting to note that even though university students ranked course availability as their greatest attraction to their universities, this was not reflected in the actual choice decision. When confronted with practical situations in which they had to consider all factors and make some trade-offs, academic reputation and employability had a more significant bearing on the choice of university than course availability. Teaching quality and employability seem to weigh heavily on the university choice decision probably because of Zambia's poor economic situation. For instance, many university lecturers in both private and public universities engage in consultancy work to earn extra income to supplement their wages. This means that there is a reduced level of commitment to their teaching obligations, resulting in poor teaching quality. With regards to employability, Zambia has a very high rate of unemployment, particularly among the youth where it stands at $31 \%$ (Zambia Institute for Policy Analysis and Research, 2015); this makes students consider the reputation of a university's qualifications on the job market.

The research objective applicable to this phase of the study is: to establish the current position of the ZCAS brand relative to its higher education competitors in Zambia. To establish this research objective, university students' individual ranking and conjoint factor profile ratings of their universities were compared firstly with those for ZCAS students' rating of ZCAS and secondly against the principal HE branding elements in 
Zambia. Figures 5 and 6 below are simple manual graphic comparisons of ZCAS and sampled university students' perceptions of their HEIs on several brand attributes based on their individual ranking results. Both diagrams suggest that there is strong competition within the HE sector in Zambia because most of the universities are clustered together (Fill, 2006, p.378). ZCAS, in particular, has not positioned itself in a distinctive position in the market and has too many direct competitors. As can be seen from Figure 5 below, ZCAS has a fairly strong competitive position in terms of course availability; however, its competitive position in terms of teaching quality is relatively weak. According to the content analysis carried out in the initial stages of the research project, the five most considered HE branding factors in Zambia in order of importance were teaching quality, fees, course availability, facilities and employability; while course availability, teaching quality, facilities and infrastructure were perceived to be the most significant sources of competitive advantage (Kayombo \& Carter, 2016). From these findings, it can be argued, by using content analysis principles, that teaching quality, course availability and facilities are the most important higher education brand elements in Zambia.

Figure 5: Perceptual Map of ZCAS versus universities (course availability versus teaching quality)

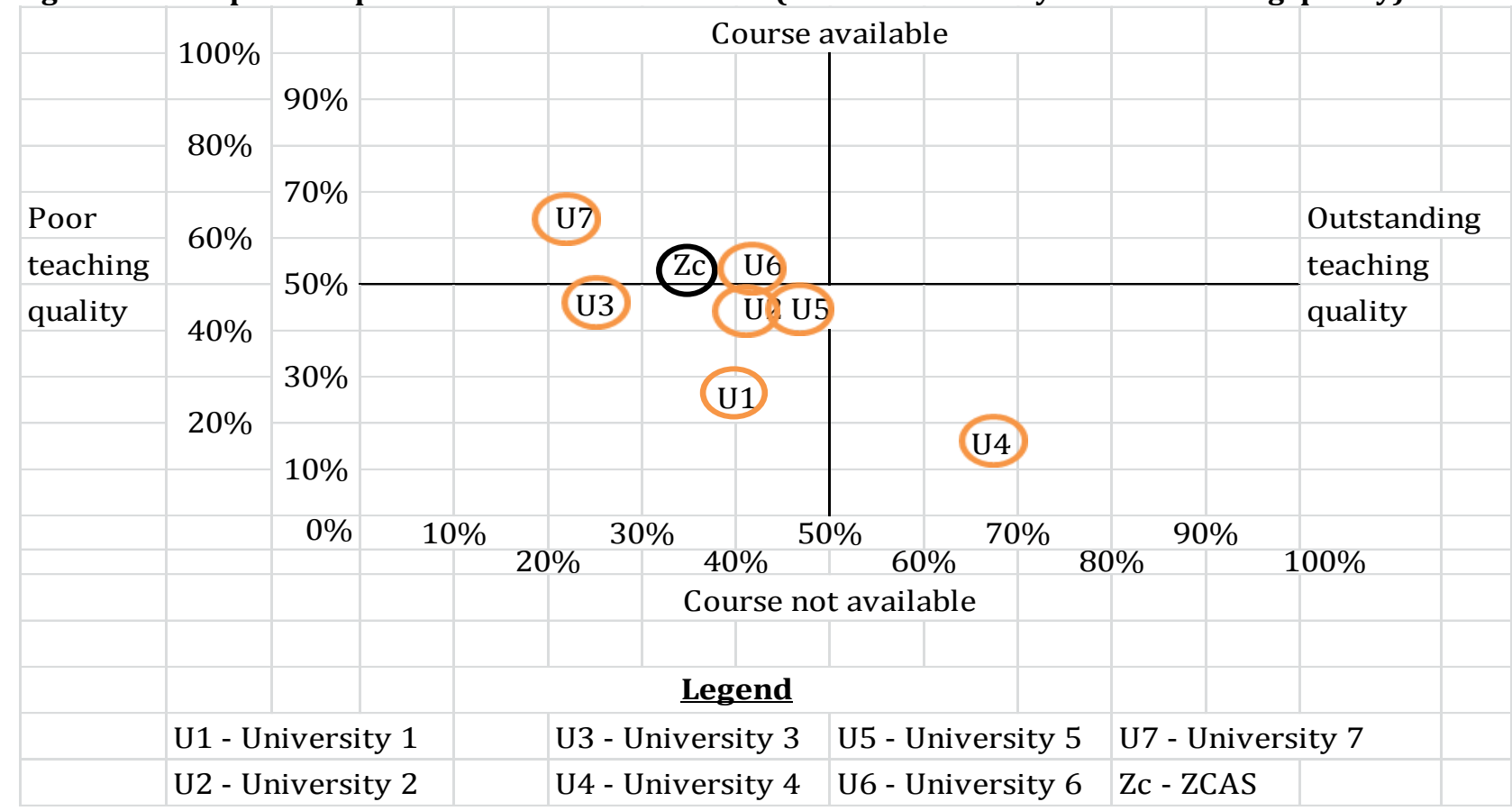

Zambian university students value teaching quality, employment prospects and course availability more than the other factors when confronted with practical situations in which they have to consider all factors and make some trade-offs in the choice of a university (see Figure 4 above). Their ZCAS counterparts chose the institution because of teaching quality, course availability and environment (which includes facilities). With regard to learning environment and job prospects, ZCAS has a slight competitive edge over some of its competitors (see Figure 6 below). 
Figure 6: Perceptual Map of ZCAS versus universities (environment versus employability)

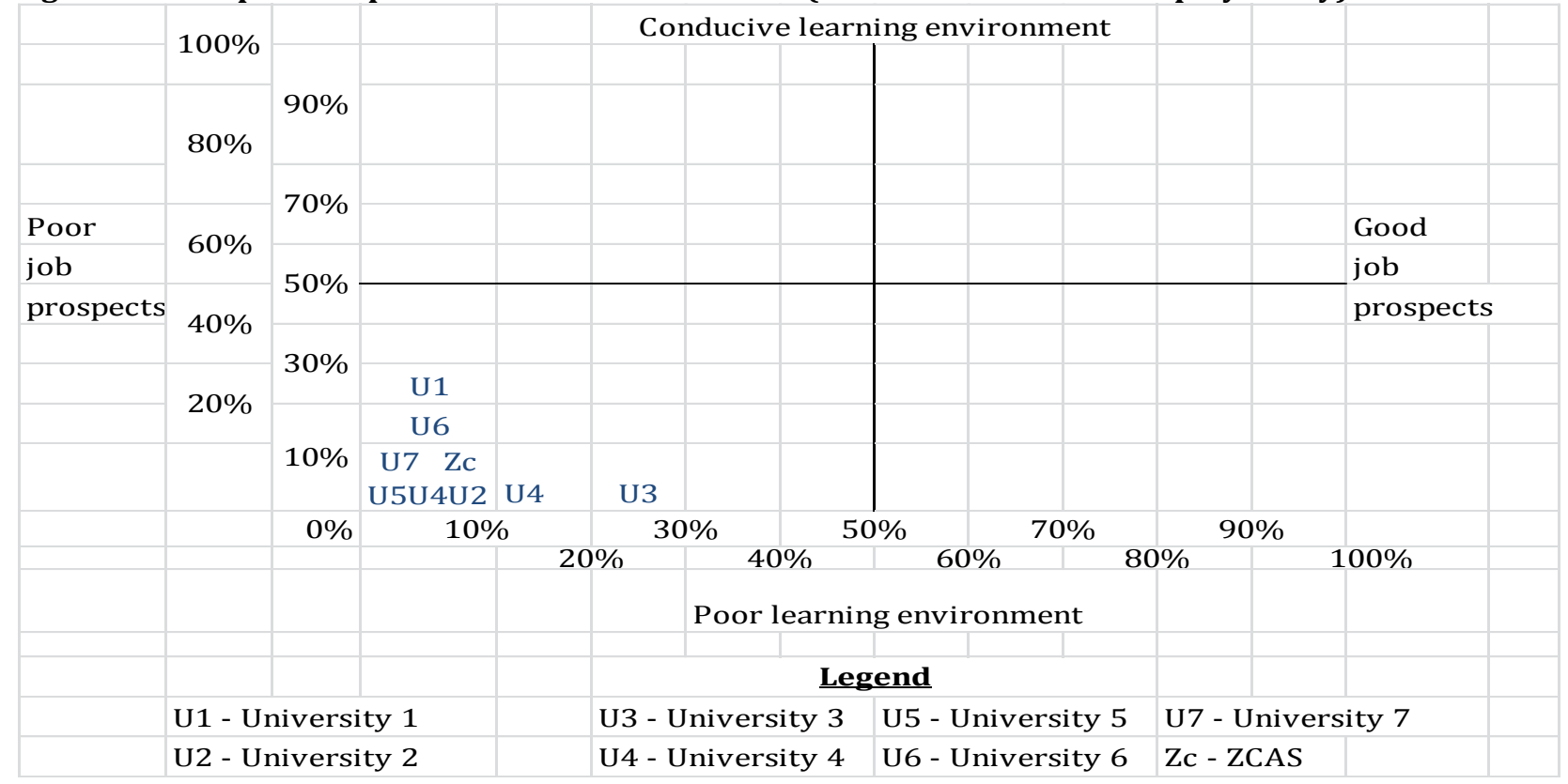

ZCAS therefore seems to be competing fairly well not only in terms of how it is perceived by students in the Zambian HE market but also when it comes to student choice of HEIs. This is because the reasons for choosing ZCAS are in line with the most important brand perceptions in the country and similar to those for university students. However, ZCAS needs to reposition itself away from the competition in order to gain a more distinct position in the minds of customers and prospects.

5. Managerial implications of the study: This section suggests steps that ZCAS can take to become more competitive in the Zambian HE market. As discussed above, students seem to be attracted to ZCAS because of its outstanding teaching quality, highly reputed courses and conducive learning environment. These factors are also the most important branding elements and sources of competitive advantage in the Zambian HE environment. Recommendations on how ZCAS can become more competitive are based largely on these factors.

Course availability: As discussed above, course availability was ranked as the number 1 attraction for ZCAS students because the institution does not only provide tuition for world renowned professional qualifications but also offers undergraduate and postgraduate degree programs in collaboration with highly ranked world class HEIs. However, ZCAS' position on the perceptual map on course availability (see Figure 5) suggests that the institution needs to do more to get ahead of the competition. ZCAS needs to introduce more programs of its own as well as in collaboration with renowned HEIs. However, the current collaborations the institution has with UK universities are very expensive to maintain mainly due to high costs of quality assurance requirements. The relatively high student fees charged by these universities coupled with a weak local currency also make the programs very expensive for the majority of interested candidates to afford.

\section{Recommendations:}

- In addition to introducing its own programs, ZCAS should try to enter into collaborations with top HEIs in the Southern African region, particularly with South African universities such as the University of Cape Town and the University of South Africa that are highly ranked (4ICU, 2016; Times Higher Education, 2016) to possibly cut down on collaboration franchise costs. According to UNESCO-UIS (2012), South African universities attract more students from the sub-Saharan region than any other country because South Africa has one of the most extensive tertiary education systems in Africa. ZCAS can therefore benefit from these universities' strong brands. The close 
proximity to South Africa, compared to Europe, for example, implies that quality assurance costs are likely to be much lower.

- The Director Academic Studies, who has overall responsibility for introducing new degree programs, could contact top South African universities with a view to entering into a collaboration agreement to offer a number of their programs at ZCAS. Considering that this process is quite long, any new programs should be earmarked for introduction in 2018-19 to enable ZCAS adequately prepare for the launch.

Teaching quality: As discussed above ZCAS students identified teaching quality as a major source of competitive advantage in the country. ZCAS' comparative position on teaching quality indicates that the institution is behind its competitors on this attribute (see the perceptual map at Figure 5). Even though the institution has stringent quality control standards, there is need to strengthen its quality control framework to become more competitive. An increase in the number of teaching staff with higher academic qualifications, especially doctorate degrees, might also help improve students' perception of the institution's teaching quality.

\section{Recommendations:}

- Even though ZCAS has a quality assurance policy, there is currently no specific person or group of people solely responsible for quality assurance. In order to ensure that a more holistic approach to quality assurance (not just teaching quality) is adopted, the CEO should appoint a quality officer to implement and enforce the quality assurance policy and procedures.

- In the meantime, the CEO should consider setting up a budget line for establishing a fully-fledged unit or department of properly trained staff in the 2018 or 2019 annual budget. The quality assurance unit or department could be in place to design, implement and monitor quality control within the institution in the next two years or so.

- With regard to qualifications of teaching staff, ZCAS must continue supporting its employees who are pursuing doctorate studies. However, the benefits from this exercise are likely to be realized in the medium to long term as doctorate studies take a long time to complete. In the short term, the institution should engage teaching staff with doctorate degrees, especially on its postgraduate programs, in order to boost students' perception of the institution's teaching quality. Such lecturing staff could be engaged on part-time basis to reduce staff costs. The Director Academic Studies, who has overall responsibility for running undergraduate and postgraduate degree programs, should engage more staff with doctorate degrees to teach on postgraduate programs. Given that the institution is planning to introduce more postgraduate programs during the academic year 2017/2018, three more lecturing staff with doctorate degrees should be targeted for part time employment to add to the existing complement.

Learning environment: The learning environment was ranked third among the five factors that attract students to ZCAS and was also the third most influential factor on student choice decision in the conjoint experiment. ZCAS has a very good learning environment; from the researcher's observations during visits to most universities in the country, very few have as good infrastructure and facilities as ZCAS. However, this competitive advantage is not sustainable because it can easily be copied as long as one has financial resources. In fact several HEIs are currently developing new infrastructure and improving their facilities. The perceptual map at Figure 6 above suggests that ZCAS needs to do more to improve students' perception of its learning environment.

\section{Recommendations:}

- ZCAS should continue maintaining its infrastructure and facilities in top operational condition. The Registrar, who has overall responsibility for maintenance of the institution's infrastructure, should provide for an adequate annual budget line for maintenance purposes. This should include expenditure on re-painting the buildings, cleaning of classrooms, offices and the surroundings, replacement of broken classroom and office furniture, landscaping and refuse collection.

- ZCAS started offering its services on the Copperbelt (about $400 \mathrm{~km}$ north of Lusaka) in order to bring education closer to this market. However, the institution has no infrastructure of its own and uses rented accommodation to run its operations there. ZCAS should consider setting up permanent 
infrastructure and facilities in order to maintain a high standard of service delivery and cut down on renting costs. The institution should consider providing a budget line for acquisition of land and/or buildings in Kitwe in the next five years.

Limitations of the study and directions for future research: There are a number of shortcomings to the current study which restrict generalizing its findings to the entire HE sector in Zambia. These limitations provide opportunities for further research. Firstly, only students that had already made the decision to choose particular HEIs were involved in the conjoint study. This excluded many of the school leavers who considered higher education but failed to achieve their objective. Targeting school leavers who are in the process of making the HE choice decision could have identified factors that potential students consider. Many researchers such as Moogan et al. (2001) and Souter and Turner (2002) adopted this approach. Marketing strategists could then devise more relevant strategies on how to attract these potential students to their institutions. Secondly, the university sample was considered to be homogenous and no cluster analysis was carried out. It is possible that within the Zambian HE sector, different groups of candidates, perhaps based on their socio-economic status, have different preference structures when it comes to choice of university. For example, some conjoint studies such as Kusumawati (2011) and Hooley and Lynch (1981) identified clusters of students with different attribute preferences within the same HE market. Future studies could therefore carry out cluster analysis to identify market segments, if any, for whom specific branding elements are more important than others. This could help market nichers develop more relevant marketing strategies, plans and tactics.

Acknowledgement: The research reported in this paper was carried out as part of a program of study for a doctorate in business administration (DBA) at the Edinburgh Business School, Heriot-Watt University.

\section{References}

4ICU. (2016). 2016 University Web Rankings | Africa: Top 200 Universities and Colleges in Africa [Online]. Retrieved from: http://www.4icu.org/top-universities-africa/ . Accessed on 25th April 2016.

Afful-Broni, A. \& Noi-Okwei, C. (2010).Factors Influencing the Choice of Tertiary Education in a Sub-Saharan African University. Academic Leadership, 8(2).

Ali-Choudhury, R., Bennet, R. \& Savani, S. (2009) University marketing directors'views on the components of a university brand. Int Rev Public Nonprofit Mark, 6, 11-33.

Bryman, A. \& Bell, E. (2011). Business Research Methods( $3^{\text {rd }}$ d), New York: Oxford University Press.

Carter, S. \& Yeo, A. (2009). My place or yours? Perceptions of, and selection choice criteria for, higher education institutions: the case of UK and Malaysian students. International Journal of Economics and Business Research, 1(2), 65-190.

De Chernatony, L., McDonald, M. \& Wallace, E. (2011). Creating Powerful Brands, 4th Edition. Oxford: Taylor \& Francis Ltd.

Dibb, S., Simkin, L., Pride, W. M. \& Ferrell, O. C. (2006). Marketing Concepts and Strategies (5 ${ }^{\text {thed). European }}$ Edition. Boston: Houghton Mifflin.

Fill, C. (2006). Simply Marketing Communications, Essex: FT Prentice Hall.

Hagel, P. \& Shaw, R. (2008). The Influence of Delivery Mode on Consumer Choice of University. European Advances in Consumer Research, 8(2).

Hair, J. F., Black, W. C., Babin, B. J. \& Anderson, R. E. (2010). Multivariate Data Analysis (7thed), New Jersey: Pearson Education.

Hooley, G. J. \& Lynch, J. E. (1981). Modeling the Student University Choice Process Through the Use of Conjoint Measurement Techniques. European Research, 9(4), 158-170.

Huang, H. (2012). An empirical analysis of the strategic management of competitive advantage: a case study of higher technical and vocational education in Taiwan. PhD Thesis, Victoria University.

IBM. (2011). IBM SPSS Conjoint 20 [Online] Retrieved from: http://www01.ibm.com/software/analytics/spss/products/statistics/library.html.Accessed on 27 November 2011.

Kayombo, K. M. \& Carter, S. (2016). Understanding student preferences for university choice in Zambia. Journal of Education Policy, Planning \& Administration, 6(3), 1-21. Retrieved from: http://www.jeppa.org. 
Kotler, P. \& Keller, K. L. (2012). Marketing Management (14thed), Essex: Pearson Education.

Kotler, P. \& Armstrong, G. (2005). Principles of Marketing (11 thed), New Delhi: Prentice Hall.

Krampf, R. F. \& Heinlein, A. C. (1981). Developing Marketing Strategies and Tactics in Higher Education Through target Market Research. Decision Sciences, 12(2), 175-193.

Kusumawati, A. (2010). Privatization and marketisation of Indonesian public universities: a systematic review of student choice criteria literature. Paper presented at the Indonesian Student International Conference, Melbourne, Australia.

Kusumawati, A. (2011). Understanding Student Choice Criteria for Selecting an Indonesian Public University: A Conjoint Analysis Approach. Paper presented at SBS HDR Student Conference, University of Wollongong.

Mazzarol, T. \& Soutar, G. N. (1999). Sustainable competitive advantage for educational institutions: a suggested model. The International Journal of Educational Management, 13(6), 287-300.

Moogan, Y. J., Baron, S. \& Bainbridge, S. (2001). Timings and trade-offs in the marketing of higher education courses: a conjoint approach. Marketing Intelligence \& Planning, 19(3), 179-187.

Lynch, R. \& Baines, P. (2004) Strategy Development in UK Higher Education: Towards resource-based competitive advantages. Journal of Higher Education Policy and Management, 26(2).

Porter, M. E. (1985) Competitive Advantage: Creating and Sustaining Superior Performance, New York: Free Press.

Ries, A. \& Trout, J. (2001). Positioning: The Battle for Your Mind (20 thed), New York: McGraw-Hill.

Saunders, N. K. M., Thornhill, A. \& Lewis, P. (2009). Research Methods for Business Students $\left(5^{\text {th }}\right.$ ed),London: Apprentice Hall.

Songan, P., Sam, H. K., Tonga, G., Rahman, M. A. \& Wah, T. K. (2010). Factors Influencing Student Choice: A Study of a Malaysian Public University. Asian Journal of University Education, 6(1), 75-89.

Soutar, G. N. \& Turner, J. P. (2002). Students' preferences for university: A conjoint analysis. The International Journal of Educational Management, 16(1), 40-45.

Times Higher Education. (2016). World University Rankings 2015-2016 [Online].Retrieved from: https://www.timeshighereducation.com/world-university-rankings/2016/worldranking\#!/page/0/length/25/country/165/sort_by/rank_label/sort_order/asc/cols/rank_only. Accessed on $25^{\text {th }}$ April 2016.

UNESCO-UIS. (2016a). Higher Education [Online].Retrieved from:http://uis.unesco.org/en/topic/highereducation.Accessed on 9 January 2017.

UNESCO-UIS. (2016b). Outbound Internationally Mobile Students by Host Region (Online).Retrieved from:http://data.uis.unesco.org/Index.aspx?DataSetCode=EDULIT_DS\&popupcustomise=true\&lang= en.Accessed on 9 January 2017.

UNESCO-UIS. (2012a). New patterns in student mobility in the Southern African Development Community: UIS Information Bulletin No. 7 [Online]. Retrieved from: http://www.uis.unesco.org/FactSheets/Pages/default.aspx?SPSLanguage=EN.Accessed on 25 April 2016.

UNESCO-UIS. (2012b). Table 14: Tertiary Indicators [Online] Retrieved from: http://stats.uis.unesco.org/unesco/TableViewer/tableView.aspx?ReportId=167\&IF_Language=eng. Accessed on 8th April, 2012.

Wiese, M., van Heerden, N., Jordaan, Y. \& North, E. (2009). A marketing perspective on choice factors considered by South African first-year students in selecting a higher education institution. Southern African Business Review, 13(1), 39-60.

Zambia Institute for Policy Analysis and Research. (2015). ZIPAR launches ground breaking 'More and Better Jobs' flagship project [Online]. Retrieved from: http://zipar.org.zm/8-newsroom/33-zipar-launchesground-breaking-more-and-better-jobs-flagship-project.Accessed on 27 June 2015. 